\title{
POST-SECULARISM OR LIBERAL-DEMOCRATIC CONSTITUTIONALISM?
}

\author{
Veit Bader
}

\begin{abstract}
The increasingly fashionable concept and framing of post-secularism aims to construct simplistic dichotomies and clear-cut ruptures between pre-secular, secular and post-secular ages or epochs, in order to paint generalised and homogenised pictures of societies and their inevitable evolution. This conceptual strategy drastically reduces, or even neglects, historical contingency and societal complexity. Against the background of a brief reflection on the possibilities and limits of a transcultural and transhistorical concept of religion, this article engages in a critical discussion of 'Secularisation and the Conditions of Post-Secularism' from a sociological point of view and critically reflects on some of the 'normative issues of how citizens' of a 'post-secular society should understand themselves'. In this regard, the main assertion is that we should opt to drop both secularism and post-secularism from our constitutional and legal language, and replace it with priority for liberal democracy or, more specifically, with liberal-democratic constitutionalism.
\end{abstract}

Keywords: Religion; secularisation; secularism; post-secularism; liberal-democratic constitutionalism

\section{Introduction}

Post-secularism is clearly the most fashionable buzzword in recent discussions on the changing relations between religion on the one hand and politics, law and the state on the other in the $21^{\text {st }}$ century. One may even be forced to use it to write a successful application for research grants and proposals. Yet buzzwords may also be highly misleading. The intention of this article is to highlight some critical issues. In a descriptive and explanatory perspective, the diagnosis of post-secularism responds to a seemingly inerasable need to capture supposed changes in one catchy phrase, whether it is post-modernism, postmaterialism, post-capitalism, post-industrialism or post-histoire. Ironically, many of these post-narratives, presented as the end of grand narratives reproduce grand narratives. From a birds-eye view they construct simplistic dichotomies and clear-cut ruptures between ages or epochs, and paint generalised and homogenised pictures of societies and their inevitable evolution; in short, they reproduce, in Roberto Unger's terminology, 'false, structural and evolutionary necessities', drastically reducing, or even ignoring, historical contingency and societal complexity. Even if presented as distant social science concepts, they are politically and normatively loaded fighting terms, used in symbolic and political power-games.

After a brief reflection on the possibilities and limits of a transcultural and transhistorical concept of religion (Section 2), this article will critically discuss 'Secularisation and the Conditions of Post-Secularism' from a sociological point of view (Section 3), before finally reflecting on some of the 'normative issues of how citizens' of a 'post-secular society should understand themselves' (Section 4). The main assertion of this article is that we should opt to drop both secularism and post-secularism from our constitutional and legal language, and replace it with priority for liberal democracy or more specifically, with liberal-democratic constitutionalism (LDC).

Professor emeritus of Social and Political Philosophy and of Sociology, University of Amsterdam.

J. Habermas, 'Notes on a Post-secular Society' (2008) <www.signandsight.com/features/1714.html>, at 4 . 


\section{A Critical Trans-Cultural Concept of Religion: 'Euro-Centric Myth' or Practical and Theoretical Work in Progress?}

Religion is, as we know, a complex, historically and socio-culturally embedded, essentially contested concept. Two well-known characteristics of religion make it nearly impossible to find a common and objective meaningful term: firstly, the huge variety of types of religion and, secondly, the increasing acknowledgment that definitions, or observations, of religions are inevitably rooted in competing religious and cultural traditions themselves. This seems to exclude any possibility of independent, neutral, transcultural or universalist definitions or second-order observations of religions.

Historical as well as contemporaneous types of religions differ widely with regard to many interrelated dimensions: (i) Do they distinguish between an immanent and a transcendent world, and if so, with which semantics (e.g. unfamiliar versus familiar, far versus near, invisible/unobservable versus visible/observable, otherworldly versus this-worldly, infinity versus finiteness, heaven versus earth, sacred versus profane)?; (ii) How is the transcendent - spirits, powers, gods, God, nirvana, self, Brahman described and how is it evaluated (good, bad, indifferent or horrible)? (iii) How are the borders between the transcendent and the immanent marked, and what places, times, events, objects or actions are considered sacred?; (iv) How is the transcendent shown, and how does it show itself and make itself known in this world? Are there any special mediators or specialised roles needed to transgress these borders - magicians, shamans, witches, seers, storytellers (mytho-poietès), priests, prophets, holy men, monks or preachers - and if so, how is the relationship between the various kinds of religious elites and lay people structured? (v) Are they belief-centred or centred on practices not only cults, rites and rituals, but also habits, ethos, virtues and the different bodily or spiritual techniques used (trances, dancing, singing, asceticism, meditation, praying, etc.) - and how are the beliefs and practices related to each other, evaluated, transmitted and learned?; (vi) Is religious belief transmitted orally (e.g. as mythos) or by written text, and, if the latter, are there any attempts by experts (e.g. rabbis, theologians, sheiks or ayatollahs) to make these holy books and texts consistent and systematic (dogmatising canons, rules and regulations)?; (vii) Is the community of practitioners bound together solely by shared practices or beliefs, or is it complemented by more or less formalised and hierarchically structured organisations (orders, temples, monasteries, mosques, churches, congregations) and authoritative rulers (bishops, popes, patriarchs)?

Under recent conditions of contested globalisation, awareness has grown of the huge diversity of competing types of religion and the critical sensitivity against contested evolutionary civilization and the (implicit or explicit) imperialist or Eurocentric definitions and descriptions of religion. The increasing religious diversity or pluralisation of the religious landscape, both globally and within Western states, seems to be accompanied by an ever-increasing fragmentation of organised high religions, putting pressure on existing forms of institutionalisation of religions and their management by the state. These developments have greatly contributed to a reconsideration of traditional concepts of religion - embedded in the Christian tradition - in the social sciences as well as in normative disciplines, particularly law and jurisprudence. Let us begin with the latter by discussing some of the practical challenges.

The development of the jurisdiction of the US Supreme Court in famous religious cases - concerning polygamy, the flag salute, conscientious objections and other exemptions, as well as the use of drugs - exemplify and illustrate the aforementioned reconsideration. The Supreme Court's mounting difficulties in finding defensible definitions of religion under conditions of greater and manifestly visible religious diversity are excellently analysed by Galanter and in a HLR Note. ${ }^{2}$ Originally, the Court's decisions showed an unreflective and unrestricted bias in favour of the national majority religion of

2 M. Galanter, 'Religious Freedoms in the United States: A Turning Point', Wisconsin Law Review 2, at $235 \mathrm{ff}$ and 260ff (1966); Note 'Developments in the Law: Religion and the State', 100 Harvard Law Review 7, at 1622-1631, 1647ff (1987). On similar difficulties in other countries and international covenants, see V. Bader, Secularism or Democracy? Associational Governance of Religious Diversity (2007), at 301 (note 3). 
(Protestant) Christianity (e.g. in the famous anti-polygamy rulings against Mormons). This stance, even when broadened to include Catholicism and Judaism, was monotheistic or at least theistic (God, supreme being), dogmatic (favouring derivative theological articulation over religious activity), belief-centred (discriminating against ritual-centred religions) and content-centred (favouring so-called high or civilised religions over low or barbarian ones). The perspective of the dominant religious majority, implicitly or explicitly endorsed by the Court, was disguised as an objective standard. During a long, and still ongoing, process of learning - stimulated by conscientious objection cases - most of the essential parts of this definition have been dropped. In recent cases, the Court has used very broad, ecumenical, permissive and subjective definitions of religion, focusing on the perspective of the claimant.

Yet, the practical dangers of such an all-inclusive and subjective definition are so obvious that the Court applies an uneasy mix of criteria, such as sincerity, centrality (not to all religions but to the particular religion in question), time and some measure of shared public understanding, to prevent the paradoxical results of the new latitudinarianism (especially in exemption cases). ${ }^{3}$ Attempts to avoid legal definitions of religion (by explicit legislation or jurisdiction) are counterproductive from a liberal rule-of-law standpoint because, in my view, they would only increase the fairly unlimited and uncontrolled discretion of administrations.

The same difficulties in finding a defensible balance between extremely broad cultural definitions of religion that seem to exclude nearly nothing, and more specific (e.g. ethnicised) definitions that seem to be too narrowly linked to specific religions, are characteristic of recent scientific discussions. It seems fairly safe to say that all attempts to press the enormous diversity of religions into the Procrustes bed of one ontological, epistemological, anthropological or psychological ${ }^{4}$ concept of the essence of religion have failed. Alternative attempts by sociologists of religion are, inevitably, more abstract and promising but are also confronted by considerable difficulties. Firstly, they have to start from reflections on the factual 'poly-contextuality of descriptions of religions'. Competing religions observe and define one another, and the external descriptions by social scientists are neither simply neutral, nor objective (the observations of sociology are observed by others, religions among them), nor can they try to replace them, as criticism of religion and the non-reflective comparative science of religions has attempted for so long. Secondly, sociologists who try to give functional definitions of

\footnotetext{
See under 'The One and the Many' in Galanter, above n. 2, at 271. In relation to Canada see the case, Syndicat Northcrest v. Amselem, [2004] SCC 47, [2004] 2 S.C.R. 551. 'The state is in no position to be, nor should it become, the arbiter of religious dogma. Although a court is not qualified to judicially interpret and determine the content of a subjective understanding of a religious requirement, it is qualified to inquire into the sincerity of a claimant's belief, where sincerity is in fact at issue. Sincerity of belief simply implies an honesty of belief and the court's role is to ensure that a presently asserted belief is in good faith, neither fictitious nor capricious, and that it is not an artifice. Assessment of sincerity is a question of fact that can be based on criteria, including the credibility of a claimant's testimony, as well as an analysis of whether the alleged belief is consistent with his or her other current religious practices. Since the focus of the inquiry is not on what others view the claimant's religious obligations as being, but what the claimant views these personal religious 'obligations' to be, it is inappropriate to require expert opinions. It is also inappropriate for courts rigorously to study and focus on the past practices of claimants in order to determine whether their current beliefs are sincerely held. Because of the vacillating nature of religious belief, a court's inquiry into sincerity, if anything, should focus not on past practice or past belief but on a person's belief at the time of the alleged interference with his or her religious freedom' (at 3). See P. Jones, 'Choice, Belief, and Responsibility', Paper presented at the Conference on 'Autonomy, Authenticity, Culture' in Brussels, at note 10 (2010) for some UK rulings. The Canadian Court is much clearer in distinguishing between judging culture and judging individual commitments than the US Supreme Court, which has mixed the subjective criteria of sincerity with objective criteria of existing cultural practices and also tried to objectify sincerity. Yet, in sincerity tests, questions regarding the consistency of practices and beliefs and of duration are relevant.

4 See David Martin's response to 'Primordialists and Constructionists: A Typology of Theories of Religion' by Eric Kaufmann, LSE Forum on Religion Lecture (2012).

$5 \quad$ N. Luhmann, Die Religion der Gesellschaft (2000), at 352.
} 
religion also have to answer the demanding questions: '[W] ho is the observer when asking for the function of religion? Whose interests regulate the scope of the intended comparison? Who is distinguishing which problem of reference?'. ${ }^{6}$ Thirdly:

In the recent religious system of global society there seems to be no 'civilizatory' progress as had been expected in the 18th century - the confidence "that the totality of religious forms could, from the perspective of a second-order observation, be grouped into primitive or civilized, barbarian, traditional or modern, eventually assuming a 'post-conventional' phase of individualized religious self-expression and corresponding communications" ${ }^{\text {"7 }}$ neither in the direction of an increasing penetration of religion with secular elements nor in that of a moral and cultural ecumene. This 'historicization' of the complexity has already been an answer to the emerging polycontexturality of religious descriptions ... Today, this is no longer possible or it can be easily uncovered as 'Euro-centrism'.

Finally, concepts of evolution and the functional differentiation of societies, which attempt to avoid implicit or explicit assumptions of civilisatory progress, have to analyse historic- and religion-specific semantic elaborations of the religious code. In addition, the function of religion has to be compatible with different degrees of differentiation of societies.

This article supports the view that Luhmann's concept and theory of religion is the most reflective, systematic and satisfactory approach for the following reasons:

i) It runs contrary to the typical reaction of sociologists like Luckmann, ${ }^{9}$ who have tried to weaken the demands on the concept of religion by either completely subjectivising it - religion then dissolves into religious experience or religious intents or the arbitrary claims of believers and practitioners (like art dissolves into what artists declare to be art) - or by completely historicising or particularising it ( $\mathrm{as} \mathrm{Asad}^{10}$ or Balagangadhara, like all genealogists, do). A meaningful scientific concept requires limitations. It has to exclude something, it has to spell out the perspective of the first- or second-order observers, and it has to define the specific reference problem religions try to answer, as well as the specific function religion fulfils. Genealogists such as Asad or Robertson also have to answer the question: Genealogy of what? When the 'idea of religion' is exported/imposed by 'the West' and adapted/transformed by 'the East', some 'family resemblance' ${ }^{11}$ is still required. Robertson's own concept of religion ${ }^{12}$ is clearly inadequate in this regard. The attempt to circumvent any theoretical definition of religion and to concentrate on (historical, structural and cultural) conditions of the changing genealogies of everyday and scientific concepts ${ }^{13}$ may avoid subjectivism, but obviously fails to demarcate the object of such changes. For example, the claim that religion has recently changed from belief and practice to identity demonstrates this, since one still has to explain what is religious about identity definitions. For fear of essentialism one loses sight of distinctions and may end up with strange comparisons. One related alternative would be to use a Wittgensteinian framework and to view religions as language games (as

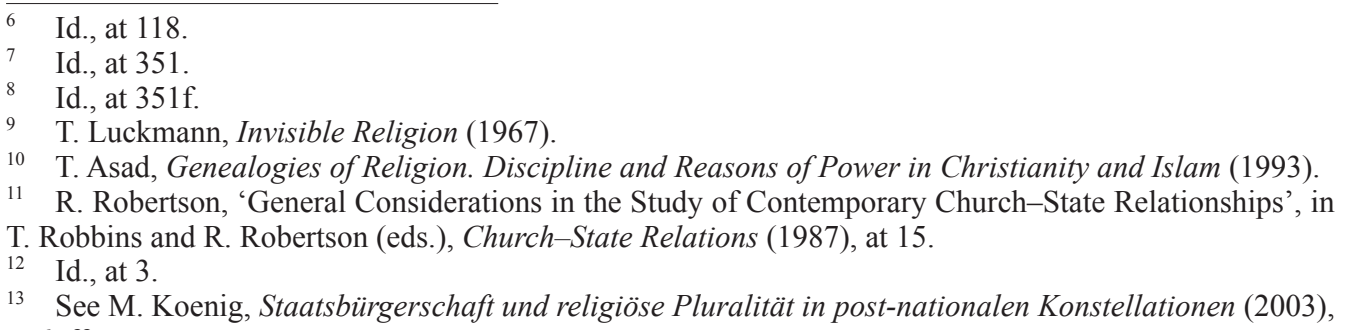


suggested to me by Bobby Sayyid). ${ }^{14}$ Such an approach would also allow for a non-subjectivist or collective definition of 'shared' religious practices, focus on contexts and help to avoid not only any essentialist definitions, but also any search for higher or deeper meta-rules. It would, however, run into the same trouble as a purely genealogical view. ${ }^{15}$

ii) It explicitly avoids the evolutionary assumptions that all religions in modernity become exclusively belief-centred and subjective, following a misguided mythical idea of radical Protestantism as an evolutionary endstate of religion in (post-) modernity, and thus implying, if not soliciting, a Protestantisation of Catholicism, Orthodox Christianity (and Lutheranism and Anglicanism), Islam and Hinduism. ${ }^{16}$

iii) Even belief-centred conceptions should not lose the specificity of religious symbolism, meaning, sense and identity, instead of being dissolved into cultural symbolism (Geertz, Luckmann) or (more or less dogmatically articulated) ideologies or symbolic universes (such as Marxism-Leninism as a religion).

Balagangadhara criticises 'the conventional wisdom' that religion is 'a cultural universal' showing a wide variety of different 'kinds' or 'types'. ${ }^{17} \mathrm{He}$ tries to demonstrate that religion is a Western concept, that religions are not only 'the best examples of worldviews', but also 'the only examples'. In his 'partial description of the West against the background of an Asian culture', ${ }^{18}$ he tries to show that 'India' has neither a religion nor a worldview. ${ }^{19}$ Both claims can only be made plausible on the assumption that his definitions of religion and of worldview are self-evident. His definition of religion as 'an explanatorily intelligible account of the Cosmos and itself' ('both the object language and its own meta-language' ${ }^{20}$ ) restricts religions to Abrahamic, 'monotheistic' religions (Judaism, Christianity and Islam): belief-centred, textually codified (sacred or holy books), standardised cognitive worldviews that institute doctrinal or organisational authorities to settle conflicts or disputes of interpretations and to transmit and propagate (his five sociological conditions for the transmission of worldviews $=$ religions). Ironically, this dogmatic concept of religion is quite close or even identical to the original views of the US Supreme Court quoted above. It grossly fails to describe even Western religions, and is obviously completely inadequate in capturing practice- or ritual-centred, orally transmitted, non-formalized religions that have no hierarchical authorities with the powers to standardise and excommunicate. ${ }^{21}$ His

\footnotetext{
14 Balangadhara also briefly but inconsequentially refers to Wittgenstein. See S.N. Balagangadhara, 'The Heaven in His Blindness': Asia, The West, and the Dynamic of Religion (1994), at 20.

15 Yet I would concede that his analogy about the practical need for an exclusive conception of religious practices and the theoretical need is not very strong. Similar to the case of secularisation (see below), one can engage in stimulating historical and comparative research of (changes in) religious practices without trying to clarify distinctions between, for example, political or ethno-national, and religious practices in a more general way.

${ }_{16}$ See my clarification of the manifold meaning of the phrase liberalisation of religions in a critical reaction to Raymond Plant: V. Bader, 'Excluded? Included? Foundational? Religions in Liberal Democratic States', in M. Evans et al. (eds.), Religion in a Liberal State (forthcoming).

17 Balagangadhara, above n. 14.

18 Id., at 9.

19 Id., at chapter X.

20 Id., at 345.

21 Balagangadhara's position is integrally repeated by P. Shah, 'Cultural and legal logics of religion and secularisation in Europe', RELIGARE intranet WP2 paper (2011). See also my response: V. Bader, "Deep Logics' or Pragmatic, Democratic Experimentalism in Law? Comments on Prakash Shah', RELIGARE intranet WP2 paper, (June 2011): 'Cultural and legal logics of religion and secularisation in Europe' (at text A), together with a Reply to his Response (at text B) (January 30, 2011) to me 'Religion and the Myths of Secularization and Separation', RELIGARE Working Paper No. 5, (March 31, 2011). <http:// www.religareproject.eu/content/religion-and-myths-secularization-and-separation>.
} 
definition of worldview also has this ridiculously limited cognitivistic rationalist bias, excluding practical knowledge (in the broad sense) and the ways to transmit it.22

iv) Practice-centred concepts (in the tradition of Pascal) are also often in danger of losing the specificity of religious practices, as is the case with many definitions of religion in cultural anthropology that focus on rites and cults (Durkheim), on attitudes and habits (Mauss, Asad), ${ }^{23}$ or on illusio (Bourdieu) ${ }^{24}$ or on commitments of 'ultimate concern' (Tillich), or on functional equivalents like civil religion..$^{25}$ The extremely broad concept of religion in the research tradition of 'political theology' runs into the same objections. The fact, for instance, that highly practice- or ritual-centred religions (such as Hinduism) do not make a clear-cut distinction between religious and other cultural practices is, as highlighted by Balagangadhara, a bad reason to dissolve religion into culture (we could play the same game with definitions of culture, and in the end, would lose all concepts). The fact that we cannot clearly distinguish between religion and ethnicity in all ethnic religions (such as Hinduism and Judaism) does not mean that we should drop our distinctions between ethnicity (broadly understood) and religion. If we did so, we would be unable to describe and analyse ethnoreligious practices and processes of ethnicisation of religions or, viceversa, of religionising ethnicity. As in the case of all boundary-drawings - e.g. between the immanent and transcendent - the demarcations are unclear and the boundaries between religious and ethnic or, even broader, cultural practices can best be clarified by discussing cases in which the boundaries are challenged (e.g. by discussing the reasons why courts did not grant exemptions or privileges to claimants by declaring them not to be religions, and the reasons why groups claim to be religions).

v) Finally, it avoids the overly historical and religion-specific semantics of the religious code in order to distinguish between the religious and the non-religious. ${ }^{26}$

In Luhmann's latest elaboration of his auto-poetic systems theory in The Religion of Society (2000), religion is seen as a specific system of meaning and communication: 'Religion is in no way responsible for meaning as such (Sinn schlechthin)'. Religious communications - beliefs, discourses and practices - are distinguished from other communications by the use of a specific binary code: transcendent/immanent. ${ }^{27}$ Compared with earlier signifiers, this account allows for a variety of alternative ways in which the transcendence/immanence distinction is recognised and signified among

${ }^{22}$ See for a much broader concept of symbolic universes: V. Bader, Kollektives Handeln (1991), at chapter VI on 'Articulation'.

23 Asad, above n. 10.

24 P. Bourdieu, 'Sociologues de la croyance et croyance de sociologues' and 'La dissolution du religieux', in Choses dites (1987), at 106-123.

${ }_{25}$ Durkheim's influential proposal - religions have the function of building/stabilising solidarity and of morally integrating societies - has the obvious disadvantage that it neglects the fact that religions are 'primary sources of conflicts' (Luhmann (2000), above n. 5, at 121); it is untenable for functionally differentiated modern societies and more plausible for tribal societies. Its extensions to civic religions would also have to discuss possible processes of desacralisation of civic religions.

26 Luhmann's criticism of the basic distinction between sacred/profane (Durkheim) is convincing. It is a simple distinction to demarcate 'spheres'. As such, it is - like Weber's 'außeralltäglich/alltäglich' - unable to comprehend the re-entry of the distinction in 'das durch sie Unterschiedene' (Luhmann (2000), above n. 5 , at $83 \mathrm{f}$ ). This criticism enables Luhmann to demonstrate that the 're-entry of the difference between the Immanent and Transcendent in the Immanent (that is the Sacred' (id., at 127) is only one option that increasingly has to compete with the 'idea of transcendence totally without difference' or 'of an "ultimate meaning without any form" that recently and increasingly (e.g. in fashionable "negative theologies" or theories of "horizontal transcendence" [see the NWO-funded project, Horizontal Transcendence: A Humanistic Perspective on the Future of the Religious Past] results in a "de-sacralization of religion"' (id., at 127,146$)$.

27 Balagangadhara does not even discuss the transcendent/immanent code and the related problems. 
and within divergent religions (i.e. from the (both possibly and actually diverging) perspectives of specific religions, other religions, non-religious people and scientific observers). ${ }^{28}$ His analysis is clearly perspectivist: sociologists (and others) observe the observations of religions, and their observations can be observed by religions. The specific reference problem - 'indeterminability, self-referential recursivity, unobservability of the world and of the observer in the world' - is answered by religion in a way that guarantees 'the determinability of all meaning against the horizon of indeterminability present in the experience' ${ }^{29}$ This role or work of religion is seen to be highly sensitive to societal structures, evolution and diverging semantics. ${ }^{30}$ The fact that all observations and perspectives, including scientific ones, presuppose observers (who is observing?), interests and problems, and that they are embedded in history, societal and cultural structures, does not prevent or relativise scientific truth. ${ }^{31}$ However, it is more questionable whether or not Luhmann's theory of evolution and of modern society is able to avoid implicit evaluative biases.

This article takes for granted that Luhmann's concept of religion enables us to capture the full diversity of historical and contemporary types of religion. It also avoids the numerous misguided and biased exclusions inherent in monotheistic or theistic (belief-centred, dogmatic, civilisational, pure, etc.) conceptions without falling prey to dissolving religion into culture, cultural practices, discourse, meaning, communication or identity as such. It fully takes into account polycontextuality and criticises unreflective attempts to privilege specific religious perspectives, or the observations of religions or of science. In all these regards, it is fully appropriate for recent conditions of religious diversity in a globalising world. Its considered perspectivism also opens up new avenues for discussing the processes and myths of secularisation.

\section{Secularisation and the Conditions of Post-Secularism}

Do we, globally, or in the West, live in completely secularised societies and cultures, or fully secular states? Here, some of the main results of the heated old and new sociological secularisation thesis will briefly be summarised. ${ }^{32}$ The thesis has been understood in four different, interconnected ways, which have not always been analytically distinguished: secularisation as decline, as individualisation, and as privatisation of religion in modern societies, and as separation of politics or states from (organised) religions (churches).

To be concise, we do not see a general decline of religious beliefs or practices, or in membership in religious organisations, certainly not on a global scale, and also not in all Western or modern societies (most prominently not in the United States, the famous American anomaly). It is now largely accepted that a generalised decline-thesis is theoretically weak and empirically indefensible. This is also true of the generalised counter-thesis of the return or revival of religion. ${ }^{33}$ Instead, we see country-, region- and institution-specific changes in belief and practice, and increasing religious diversity.

\footnotetext{
28 What lies before this distinction in a temporal perspective 'we would not signify as religion' (Luhmann (2000), above n. 5, at 88, 322; see also N. Luhmann, Funktion der Religion (1977), at 194). This implies difficulties with traditions that do not clearly distinguish between the immanent and the transcendent, such as Confucianism (but see R. Bellah, Religion in Human Evolution (2011) versus Weber), but it is not biased in the direction of a belief-centred definition of religion. The difficulty that not all traditions we are used to calling religions distinguish the immanent/transcendent does not make this distinction worthless; the fact that not all societies distinguish between the economic and the political does not mean that we could not analyse their production and distribution systems and their decision-making structures (on the problems of differentiation and the conceptual consequences, see V. Bader and A. Benschop, Ungleichheiten (1989), at chapters III.3 and III.4).

29 Luhmann (2000), above n. 5, at 127, 141 et pass.

30 Id., at 128

31 'Methodological a-theism' or better, 'a-religiosity' (Luhmann (2000), above n. 5, at 278). See Bader (2007), above n. 2, at chapter 2 for my concept of embedded impartiality and relational objectivity.

32 See for a more detailed treatment see RELIGARE WP2 paper, above n. 21.

33 As defended, for example, by Roland Robertson or in the research-project The Future of the Religious Past funded by the Dutch science funding organization NWO.
} 
Secularisation, like individualisation has often been confounded with the thesis of inevitable privatisation of religion; however, they have to be clearly distinguished because the former does not inevitably include the latter. The individualisation-thesis itself has three different meanings: (i) A shift from practice to belief-centred religiosity: all religions, bluntly speaking, inevitably lose their collective and ritual aspects as a consequence of modernisation, and follow the path of radical (i.e. not Episcopal), Protestantism. (ii) Religions are increasingly subjectified: the core of religiosity becomes individual expression, authenticity, and identity. (iii) Religion and belonging is increasingly and inevitably seen not as a matter of fate, but as a matter of free, voluntary and contingent individual choice amongst many competing religious and non-religious options. Only the latter thesis, in my view, survives critical scrutiny, and only when it is clearly distinguished from the privatisation-thesis.

The general thesis of an inevitable privatisation of religion is theoretically and empirically implausible because of four tendencies: (i) cultural defence in majorityminority relations inside states, (ii) threatened religious identity in cultural transitions (through industrialisation and urbanisation, or through migration). In both cases, collective religious identities serve as markers of cultural and religious difference, as well as resources for organisation and mobilisation. (iii) Under conditions of serious power-asymmetries privatisation is a strategy of predominant majorities to assimilate minorities hidden under the guise of neutrality and modernity. This socio-logic of power asymmetry ${ }^{34}$ is absent in main-stream sociology of secularisation. ${ }^{35}$ It is also visible in international relations between states and religious majorities and minorities in the global arena. (iv) Finally, the thesis is contradicted by both the right-wing variety of public religion (e.g. not only Conservative or Fundamentalist, but also Evangelical Christianity) and the liberal variety of public religion (e.g. Anglican and Lutheran Protestantism). Thus, resistance to privatisation and deprivatisation are viable, modern, historical options.

Moving on, what about the inevitable complete separation of politics and state from church? It is symptomatic that even critics of the first three interpretations of secularisation ${ }^{36}$ accept the complete separation of church and state in the long run as an 'irresistible trend' in modern societies. In the long run we are all dead but in the mean time we have to acknowledge that strict separation is a (powerful) myth that does not exist even in the self-proclaimed strict separation countries. Therefore, we have to reconceptualise separation as minimal differentiation between state and (organised) religion (the two autonomies of state from churches and churches from the state) by specifying minimal thresholds of institutional, organisational and role differentiation (see below).

As a consequence of these four critical strands, the secularisation-thesis as a generalising theory and as a descriptive account of modernisation and/or modern societies should not continue to be used. In its place, a sober, brief summary of changes in the religious landscape reads roughly as follows:

On a global scale, the following simultaneous processes can be discerned: monotheistic religions compete with each other globally, engaging in aggressive missionary and proselytising campaigns. At the same time, they are caught in progressive competition with polytheistic and non-theistic world religions and their export to the West. Increasingly, animistic, spiritualist tribal religions are also going global, and religious syncretism is rising, particularly in Latin America and Africa. This situation of a more or less peaceful coexistence of divergent types of religions makes the expansion in religious diversity visible. The process may be summarised as a development 'from hegemony to pluralism'. ${ }^{37}$

C. Guillaumin, Racism, Sexism, Power and Ideology (1995); V. Bader, 'Dilemmas of Ethnic Affirmative Action', 2 Citizenship Studies 3, at 435-473 (1998); D. Juteau, L'ethnicité et ses frontières (1999).

35 Bader (2007), above n. 2, at 45.

36 Such as J. Casanova, Public Religions in the Modern World (1994); D. Martin, A General Theory of Secularization (1978) and Luhmann (2000), above n. 5.

37 G. Bouma, 'From Hegemony to Pluralism: Managing Religious Diversity in Modernity and PostModernity', 12 Australian Religion Studies Review 2, at 7-27 (1999); D. Martin, Tongues of Fire (1990), at vii f, $293 \mathrm{ff}$, and Luhmann (2000), above n. 5, at 141ff, $341 \mathrm{ff}$. 
Within Western Christian or Judeo-Christian state-societies, one also finds competing monotheisms, intensified, reactive Protestant fundamentalisms within Christianity, varieties of Islam as the old foreign enemy and the new enemy from within. There has also been the import of all types of Eastern world religions (Hinduism, Buddhism and Zen), new age sects and spirituality, ${ }^{38}$ an increased visibility of native peoples and their religions, and a massive growth of all possible forms of syncretism. The cultural and religious borderlines separating developments within and outside state societies are becoming increasingly fragile, or are breaking down. ${ }^{39}$

In sum, there is no evidence indicating a general decline of religion, or a general revival or return of religion. Religion is not generally subjectivised or privatised, and the state and (organised) religions are not strictly separated. Finally, neither societies nor states are completely secularised.

Let us now turn to a critical discussion of a descriptive account of a post-secular society. What, if anything, has changed? Do we live under conditions of post-secularism? 4 $^{\circ}$ If the above summary of the secularisation-debate is not overly crude or biased, it is astonishing that many researchers and normative theorists are attracted by the sweeping concept of post-secularism. As already stated in my introduction, like all post-concepts, it tries to capture the nеие Unübersichtlichkeit in a neat, generalising way, drastically reducing the complexity and contingency of our situation. A brief criticism of Habermas' notes on a post-secular society can demonstrate the downsides of this strategy. ${ }^{41}$ As a sociological observer, ${ }^{42}$ he gives a fairly ambiguous account of secularisation: while criticising some versions of the thesis, he still adheres to some basic tenets, as I hope to demonstrate with the following brief critical remarks:

First, Habermas does not clearly distinguish between 'a secular (and or secularized) society' and a 'secular' 43 or 'completely secularized state' ${ }^{44}$ It would at least have been worthwhile to mention that even the latter does not exist anywhere, whether or not it would be a desirable utopia.

Secondly, he reduces the scope of the secularisation thesis to 'affluent societies' (Europe, Canada, Australia, New Zealand), ${ }^{45}$ and treats the US as 'the norm'. Yet, he still ascribes this to European secular societies instead of, if anything, discussing relevant degrees and types of secularisation between different countries. In this 'revisionist view', although the rest of the world is no longer under the spell of the workings of 'Occidental rationalism'46 (whatever this may mean), Europe is still supposed to be under its influence. To each his or her own variety of modernisation or rationalisation theory.

Thirdly, Habermas keeps some distance regarding the competing claims of, on the one hand, the dramatic lapse in religious ties and the resulting tangible losses (the 'relevance of religion' has not 'waned' $)^{47}$ and, on the other hand, of a 'worldwide resurgence' of religion. Yet, his 'impression' is that evidence from the data collected globally robustly 'supports the defenders of the secularization thesis (emphasis added)' 48 (without even indicting which variety of the thesis would be supported). In all these regards we just have to trust Habermas, because arguments and empirical evidence are clearly lacking.

Fourthly, all this is supposed to be so, or even maybe has to be so, because of the "correlation between the functional specification ... and the individualization of

\footnotetext{
L. Woodhead, A Sociology of Religious Emotion (2010).

P. Levitt, God Needs No Passport (2007).

Habermas (2008), above n. 1.

I have chosen Habermas' text because of his reputation and impact, not because of scientific merits. See for a comparative presentation of Habermas, Taylor and Asad: M.G.N. Mozumder, 'Interrogating PostSecularism' (Master thesis on file at the University of Pittsburg).

42 Habermas (2008), above n. 1, at 7.

43 Id., at 1.

44 Id., at 10.

45 Id., at 1.

46 Id., at 3 .

47 Id., at 3 .

48 Id., at 5 .
} 
religious practice', the 'de-institutionalization' and 'withdrawal into a mere personal or subjective domain' ${ }^{49}$ This seems to be the explanatory part which reproduces the (in)famous mix of subjectivisation = privatisation $=$ individualisation combined with the functional necessity of strict separation (the rock-bottom and rather mythical functional explanation of secularisation referred to above).

Fifth, these descriptions (summarised sub three) and this explanation stand in a fairly uneasy, even self-contradictory relation, ${ }^{50}$ with Habermas' general 'descriptive account of a post-secular society' supposed to be the society we live in: 'Public consciousness' has to 'adjust itself to the continued existence of religious communities in an increasingly secularized environment ${ }^{51}$ on the one hand, and his 'predictions concerning the future role of religions' on the other hand. Habermas proposes three reasons 'why we can term secularized societies 'postsecular': (a) the 'secular understanding of the world' loses 'any triumphal zest', the 'secularistic certainty that religion will disappear worldwide in the course of modernisation is losing ground'; (b) 'religion maintains a public influence and relevance' 'in the political arena and the culture', or is even 'gaining influence ... also within national public spheres'; (c) continued immigration from countries with 'traditional cultural backgrounds'. ${ }^{52}$ In my view, it is rather remarkable that none of these three reasons is in any meaningful sense new or post-secular:

- If one distinguishes in the manner of Habermas (as one should) between secular and secularist, ${ }^{53}$ even a fully secular society would not be characterised by any triumphal zest or secularist certainty;

- Quite apart from the ambiguous statements that they are maintaining or gaining influence, religions have never lost a public and political role in secular societies or secular states;

- Immigration from so-called traditional societies is a basic characteristic of both internal and international migration in nearly all modern societies, certainly from the $17^{\text {th }}$ Century, and particularly the $19^{\text {th }}$ Century onwards.

One may try to rescue some elements of this empirical diagnosis of post-secularism by conceding that it does not, or is not meant to, indicate changes in the structural conditions or arrangements of societies or states, but refers only to empirical changes in mentalities or in public consciousness, as distinguished from the 'normative issues of how citizens of such a society should understand themselves'. ${ }^{54}$ Yet, one also searches in vain for any empirical evidence of the supposed changes in this regard. Thus, descriptively, one does not gain anything through the term, but looses quite a lot, since one is tricked into dichotomies, some supposed rupture, homogenised pictures and predictions, instead of detailed descriptions, changes, matters of degree and, particularly, highly contingent and contradictory processes. Obviously, post-secularism is a fighting term used against aggressive or 'militant secularism'. ${ }^{55}$ As such, it may serve limited worthwhile aims. ${ }^{56}$ Yet, it does not provide a sound empirical basis for normative debates.

\footnotetext{
49 Id., at 5.

50 See also his own doubts: "whether or not we consider the application of the predicate "post-secular" appropriate'. Habermas (2008), above n. 1.

51 Quoted from J. Habermas, Glauben und Wissen (2001).

52 Habermas (2008), above n. 1, at 5-7. As in so many other varieties of modernisation theories, the traditional/modern dichotomy has to do a lot of mystifying work (see the construction of religion as 'traditional mythos' and 'totalitairian' 'denkvorm', completely opposed to 'modernity', 'autonomy' and 'humanness' by K. van der Wal, 'Is de vrijheid van godsdienst in de moderne multiculturele samenleving nog een hanteerbaar recht?' 39 Rechtsfilosofie \& Rechtstheorie/Netherlands Journal of Legal Philosophy 2, at 133-157 (2010); see Leezenberg's criticism of Habermas in this regard: M. Leezenberg, 'How ethnocentric is the concept of the postsecular?', in A. Molendijk et al. (eds.), Exploring the Postsecular (2010).

53 Habermas (2008), above n. 1, at 17.

54 Id., at 4.

55 Id., at 13

56 For comparative social science research of the variety of secularism and post-secularism as political fighting terms see J. Casanova, 'Civil Society and Religion', 64 Social Research 4, at 1041-80 (2001), M. Wohlrab-Sahr, 'Multiple Secularities and Their Normativity as an Empirical Subject' (2012)<http://
} 


\section{Secularism, Post-Secularism or Liberal-Democratic Constitutionalism?}

This article's brief criticism of Habermas' normative considerations of 'how citizens should understand themselves in a post-secular society' ${ }^{57}$ concerns three clusters of issues: his notion of citizenship in recent states, his considerably uneasy treatment of toleration and of the inherent tensions in liberal constitutionalism and democratic constitutionalism, and his only slightly modified exclusivist secularism concerning public reasons and justifications of LDC.

Firstly, it is rather remarkable that Habermas discusses the rights and obligations - 'what must we reciprocally expect from each other' - for citizens only, implicitly or explicitly excluding denizens and other residents (all kinds of irregular migrants). This is not the place to repeat the elaborate criticism of citizenship as an exclusionary practice $^{58}$ that is still very much alive. The ambiguous phrase "membership of a postsecular society' ${ }^{59}$ could provide some openings, but even these are not used: 'the other is a member of an inclusive community of citizens' ${ }^{60}$ Inclusiveness of other or strange religions is combined with exclusiveness on the basis of the citizen/noncitizen divide. It is also remarkable that, right from the start, the discussion of rights and obligations in states with liberal-democratic constitutions is intrinsically linked to contested and, in my view, completely unnecessary assumptions on secularised, secular or postsecular societies. As already stated above, the link between LDC and secularisation secular societies is historically and empirically contested. Finally, and maybe even more astonishingly, compared with his earlier writings on the European Union, firmly entrenched nation-states ${ }^{\prime 61}$ are taken for granted. This position is deeply at odds with the multi-level polities in which most of $u s$ live, ${ }^{62}$ as well as with a viable, layered concept of European citizenship, and democratic rights and obligations for third country nationals. ${ }^{63}$

Secondly, like many others, Habermas cannot resist the logic of replacement of - in my own terms - minimal morality by more demanding liberal and democratic morality (of mere toleration by respect toleration, equality and pluralist toleration or recognition of difference.$^{64} \mathrm{He}$ persistently debunks tolerance as an 'uneasy modus vivendi' serving peace and order. ${ }^{65}$ It appears as if tolerance is not only clearly 'insufficient' for the 'liberal rule of law' and for 'democratic will' (combined in the democratic constitutional state), but would have to be replaced by equal respect for persons. Collective toleration and associational freedoms of religion seem suspect: we have to 'free their individual members' ${ }^{\prime 66}$ and we have to guarantee the 'right, as private citizens (sic) to preserve their identity ${ }^{67}$ as if collective toleration would only be a strategic modus vivendi, and not a moral principle in itself, as if collective religious freedoms could be roughshod, overridden by individual autonomy and/or non-discrimination (this would be, indeed, an intolerable liberalism), as if liberal freedoms of religion would not include external

blogs.ssrc.org/tif/2011/12/13/> (see my criticism: V. Bader, 'Normative or Empirical Comparisons?' (2012) $<$ http://blogs.ssrc.org/tif/2012/01/09/normative-or-empirical-comparisons/>) and others.

57 Habermas (2008), above n. 1, at 4, 8, 12.

58 See V. Bader (ed.), Citizenship and Exclusion (1997) and V. Bader, 'Citizenship of the European Union. Human Rights, Rights of Citizens of the Union and of Member States', 12 Ratio Juris 2, at 153-181 (1999).

59 Habermas (2008), above n. 1, at 8.

60 Id., at 12.

61 Id., at 8 .

${ }^{62}$ See V. Bader, 'Complex Legitimacy in Compound Polities. The EU as example', in S. Elstub (ed.), 'Democracy in Theory and Practice', 46 Representation 3, at 261-279 (2010).

${ }_{63}$ Bader (1999), above n. 58. at 153-181.

${ }^{64}$ Bader (forthcoming), above n. 16.

65 Habermas (2008), above n. 1, at 9f.

${ }^{66}$ See for a balanced treatment of the tension between individual and collective religious freedoms and the crucial role of exit rights and exit options: V. Bader, 'Associative Democracy and Minorities Within Minorities', in A. Eisenberg and J. Spinner (eds.), Minorities Within Minorities (2005), at 319-339; and V. Bader, 'Individual and/or Associational Autonomy? Associative Democracy and the Freedoms of Entry and Exit', in D. Borchers (ed.), Theoretical and Practical Implications of the Exit Option in Liberal Societies (forthcoming).

67 Habermas (2008), above n. 1, at 10. 
freedoms of religious practices in public, instead of the right to privately preserve their religious 'identity' ${ }^{68}$ Not only does Habermas defend a truncated version of liberal religious freedoms, he also fails to address serious tensions and conflicts between such liberal principles and rights, and 'democratic will formation'. Instead of substantively dealing with the inherent tension and conflicts of liberal and democratic rights (see also below), he presents salvatory formula such as: 'deliberative and inclusive procedures of democratic will formation', ${ }^{69}$ which have to be used to decide on what, and what will not, be tolerated. ${ }^{70}$ As a consequence of this, his criticism of the binary oppositions - on the one hand universalist Enlightenment (universalist equal citizenship) versus militant secularism/fundamentalism of Enlightenment, and on the other hand the particularist sensibilities (cultural difference) versus radical multiculturalism and communitarian collective identity freaks - remains inevitably superficial. The utopian version of democratic deliberation, is finally backed up with the 'demanding expectations of an ethics of citizenship' ${ }^{71}$ without even mentioning tensions and conflicts between basic civic and democratic virtues and without any, even the most minimalist, realism-check. ${ }^{72}$

Thirdly, Habermas repeats an only slightly modified version of his earlier exclusivist secularism: secular foundation, a secular metaphysics and secular reasoning. In his view, LDC and liberal-democratic constitutions/states presuppose 'a secular selfunderstanding of modernity'. ${ }^{73}$ Hence, 'religious citizens are expected to appropriate the secular legitimation of constitutional principles', instead of subscribing to the principles of LDC for whatever reason. This post-secular but still secular metaphysics is then connected to a very specific 'learning process', requiring a shift from a 'traditional to a more reflective form of religious consciousness', following the model of 'the postReformation change in epistemic attitudes'. The whole story is concluded by the blunt statement that 'many Muslim communities still have this painful learning process before them' ${ }^{74}$ It does not come as a surprise that Habermas has only slightly modified his secularist and rationalist public reasons restraints, ${ }^{75}$ repeating the core idea, that a 'filter between the informal political communication and opinion formation' and the 'formal agendas' of 'institutionalized decision-making (in parliament, court, government and administration)', 'through which only translated, i.e. secular contributions may pass

\footnotetext{
${ }_{68}$ See V. Bader, 'Religions, Toleration, and Liberal Democracy: A Theory of Doctrinal, Institutional, and Attitudinal Learning', in M. Mookherjee (ed.), Democracy, Religious Pluralism and the Liberal Dilemma of Accommodation (2011), at 17-46; and V. Bader, 'Moral Minimalism and More Demanding Moralities. Some Reflections on "Tolerance/Toleration", ACCEPT-Pluralism, WP2, (http://www.accept-pluralism. eu/Home.aspx) (2012); for a defence of toleration as a minimal moral principle and of associational or collective autonomies as the other side of any tolerable liberalism.

69 Habermas (2008), above n. 1, at 12.

70 This is one of the inherent limitations of his purely proceduralist theory of justice. The dangers of democratic majoritarianism can be avoided only in ideal theory, but even in theory the inherent tensions are resolved only by Habermas' old belief in the 'Gleichursprünglichkeit von privater und politischer Autonomie' (see my criticism of 'Facts and Values': V. Bader, 'Viel Geltung und immer weniger Faktizität. Zur Kritik von Jürgen Habermas' diskurstheoretischer Rechts- und Demokratietheorie', in H. Ganßmann and S. Krüger (eds.), Produktion, Klassentheorie. Festschrift für Sebastian Herkommer (1993), at 50-78.

71 Habermas (2008), above n. 1, at 18.

72 See my minimalist treatment of civic and democratic virtues: Bader (2007), above n. 2, at 180ff and $269 \mathrm{ff}$.

73 Habermas (2008), above n. 1, at 19.

74 Id., at 18. See also Y. Jansen (2011), 'Postsecularism, Piety and Fanaticism; Reflections on Jürgen Habermas' and Saba Mahmood's Critiques of Secularism', 37 Philosophy and Social Criticism 9, at 977-998; and S. Bangstad, 'Contesting Secularism: Secularism and Islam in the Work of Talal Asad', 9 Anthropological Theory, at 188-208 (2009), and S. Bangstad, 'Saba Mahmood and Anthropological Feminism After Virtue', 28 Theory, Culture \& Society 3, at 28-54 (2011). See also Bader (2011 and 2012), above n. 68, at 29-40 and website. Maeve Cook ('A Secular State for a Postsecular Society? Postmetaphysical Political Theory and the Place of Religion', in: Constellations 14/2, 2007, 224-238) also criticizes the 'translation requirement', the equation of the terms 'generally accessible' and 'secular', and Habermas' "secularist interpretation of the principle of neutrality" (231) but her replacement by the constraint of "non-authoritarian reasoning" (rejecting authoritarian conceptions of knowledge and of justification) is much 'stricter' and demanding than my constraints.

${ }_{75}$ See J. Habermas, 'Reconciliation Through the Public Use of Reason', 92 Journal of Philosophy 3, at 109-131 (1995) and J. Habermas, Glauben und Wissen (2001).
} 
(bold emphasis added)' ${ }^{76}$ This also includes the old idea that religious reasons have to be 'translated' into secular ones because only this is 'a language that all the citizens understand' (see at 21 for this 'institutional translation proviso'). ${ }^{77}$ Thus, the metaphysics has to be secular, justifications of constitutional principles have to be secular, clearly $L D C$ and $L D$ constitutions also have to be secular, and any liberal democratic state has to be a secular state. Only with regard to political communication and opinion formation 'religious persons ... are permitted to take part ... even if they use religious language'. The 'democratic state must not pre-emptively reduce the polyphonic complexity of the diverse public voices because it cannot know whether it is not otherwise cutting society off from scarce resources for the generation of meanings and the shaping of identities' ${ }^{78}$ This is still considerably less than even the late Rawls allows for. In the end, there is not much 'pressure' and 'expectations' on secular citizens. ${ }^{79}$ Instead of these refined exclusions, all (citizens, denizens, irregular migrants) should learn the language of toleration (or the language of a decent or minimally moral state), and the more demanding but still minimalist language of LDC, which both are beyond the religion/secular divide (see below). ${ }^{80}$

Thus, if we cannot learn many productive things from sociological and normative postsecularism, what can we learn from sober sociology and from alternative normative theories in a prescriptive perspective? This article begins with what I think we should learn from sober sociology in a prescriptive perspective of governance of increasing religious diversity. Four issues seem particularly pressing:

1) Difficulties of defining religion should neither be a reason to replace religion by culture (see above versus Balagangadhara and Shah), nor one of the many arguments for getting rid of freedom of religion altogether, or replacing freedoms of religion by one general principle and the right of free expression. ${ }^{81}$ Compare such a proposal with the legal development

76 Habermas (2008), above n. 1.

77 Id., at $18-21$.

78 Id., at 20.

79 Contrary to the interpretation by Shabani praising this 'two-way model' for 'altering the asymmetrical burden of reason giving', it is still myopic and heavily lopsided (O.P. Shabani, 'The Role of Religion in Democratic Politics: Tolerance and the Boundary of Public Reason', 106 Religious Education 3, at 337 (2011)). See my criticism in V. Bader, 'Secularism, Public Reason or Moderately Agonistic Democracy?' in G.B. Levey and T. Modood (eds.), Secularism, Religion, and Multicultural Citizenship (2008), at 110-135. 80 See the empirical and historical criticism by M. Leezenberg, 'How Ethnocentric is the Concept of the Postsecular?', in A. Molendijk et al. (eds.), Exploring the Postsecular (2010), at 111. Yet, Leezenberg, like Asad and other genealogists, while criticising the hidden normativism of 'liberal secularist and modernization-theoretical approaches', does not spell out his own normative perspective.

81 In the Netherlands this idea is promoted by Paul Cliteur, Patrick van Schie, and Koo van der Wal. Van Schie, the chair of the scientific bureau of the conservative liberal party VVD, argues: 'In the Netherlands we have the freedom of opinion, the freedom of association and the freedom of assembly and demonstration and with these rights you have actually already covered all the rights that are protected by the freedom of religion. So there are two possibilities. It could be the case that it's [a] relic of old times because people were more involved in religion back then. Opponents sometimes say: "yes, but that's the oldest basic right". And they are right about that but it could become redundant because other laws cover the right [to]freedom of religion. If it was just about cleaning up the Constitution technically, than we are not in a hurry and we could postpone it. But I'm afraid, and I have certain clues for that, that it's more than that and that people with religious convictions are trying to claim certain privileges based on their religion. [...] For me, a church is just an association like any other association and it should of course have the same freedoms as other organizations but nothing more than that. That actually also goes for the freedom of opinion. For me, this freedom should be broadly defined but there shouldn't be exceptions for religious motives or other motives. Every citizen has to be treated equally' (quote from RELIGARE WP7 Dutch Country Report, unpublished, (2012)). The consequences of 'de vervaging van het begrip godsdienst' (K. van der Wal 'Is de vrijheid van godsdienst in de moderne multiculturele samenleving nog een hanteerbaar recht?' 39 Rechtsfilosofie \& Rechtstheorie/Netherlands Journal of Legal Philosophy 2, at 136f (2010)), of the 'verwevenheid van religie en cultuur' (id., at 137f) and of the 'subjectivering en verinnerlijking' (id., at 146ff); 'Eigenlijk sluit alleen een sterk gesubjectiveerde, verinnerlijkte en verzedelijkte vorm van religie ... aan bij de moderne idee van godsdienstvrijheid' (id., at 152) is an increasing 'arbitrariness' of freedom of religion, particularly of conscience that can be retained as a basic legal right solely for 'pragmatic reasons' (id., at 155) because otherwise the Netherlands would have to unsubscribe also from the ECHR (see Article 9). 
of the right to non-discrimination as one general principle, which is characterised by ever more detailed specifications concerning the diverse and intersecting bases of discrimination in UN and European treatises and directives. Through such a perspective, the idea of replacing all freedoms of religion and all freedoms of expression (including artistic freedom and, internally diversified, freedoms of political communication) by one general freedom of expression, seems particularly counter-intuitive and counter-productive.

2) The increasing religious diversity or pluralisation of the religious landscape, both globally and within Western states, seems to be accompanied by an ever increasing fragmentation of organised high religions, putting pressure on existing forms of institutionalisation of religions and their management by the state, ${ }^{82}$ especially the rigid versions of selective cooperation between Church and State or religious corporatism in some European countries. In this regard, associational governance seems to be the most viable alternative (see below point 5 ).

3) If, and to the degree to which, membership in religious organisations (e.g. Churches of the big Christian denominations) is declining, this, prima facie, erodes their representativity and their relative power position in existing arrangements. Yet, if one compares organised religions, not with a nostalgically idealised past, but with contemporary competitors like humanist organisations and secularist counter-organisations (political parties in particular), the decline of the latter 'has been far more severe than anything suffered by the churches. If the contest between religion and secularization is one between organizations and articulated systems of belief, then religion rules undisturbed. Its 'enemy' is not aggressive laicism but indifference,' ${ }^{83}$ Thus, if representatives of humanist organisations complain about the unfair and unequal distribution of public subsidies amongst religious organisations and secularist organisations, they have a point. ${ }^{84}$ Yet, if they complain vocally (as they do) that they are not heard, this is clearly influenced by their weak membership base and their weak organisational and mobilisational capacities. Their individual voice is also noise.

4) If, and to the degree in which, religions (old or new) would really subjectivise, if they would stop raising any public and political collective claims and would become truly invisible, if, in other words, they lose their organisational and mobilisational capacities, or explicitly choose to be completely privatised - their individual voice is noise as well - so be it. In the extreme, such a scenario may result in the absence of any, or of specifically organised, religious voices, as well as of secularist voices and, eventually, in more or less full indifference of atomised and privatised individuals. If people opt for this under conditions of not too serious inequalities and of full freedoms of political communication (including guarantees of associational autonomy), this may fundamentally change the social, cultural and pre-political conditions of liberal-democratic politics and states; however, it is not an issue of fairness.

5) As already indicated, the claim of this article is that associational governance $^{85}$ of religious diversity is more appropriate under these

\footnotetext{
82 G. Bouma, 'From Hegemony to Pluralism: Managing Religious Diversity in Modernity and PostModernity', 12 Australian Religion Studies Review 2, at 7-27 (1999) and G. Bouma, 'A Comparative Study of the Successful Management of Religious Diversity: Melbourne and Hong Kong', 19 International Sociology 1, at 5-24 (2004).

83 C. Crouch, Social Change in Western Europe (2000), at 273 and C. Crouch, Post-Democracy (2004).

84 Such as Sophie in 't Veld at the RELIGARE policy meeting in the building of the European Parliament in Brussels, June 30, 2011.

${ }_{85}$ Associative Democracy is a specific variety of liberal-democratic institutional pluralism, which combines
} 
conditions of increased religious pluralism and fragmentation of organised high religions, and hence preferable to the two other prominent but idealised models: American denominationalism and selective cooperation regimes in some European states. We have more options, and should avoid being trapped into a simplistic choice between either a fully secularised state based on an idealised version of American denominationalism or French republicanism (with strict separation of state and politics from privatised religions), or existing neo-corporatist or pillarised European regimes of selective cooperation between states and organised religions, even if stylised as models of moderate secularism (Modood). Contrary to strict separation-ideologies, all states, including the US and France, recognise organised religions either legally or administratively, finance them either directly or indirectly (tax-exemptions), and privilege freedoms of religion by granting them, and not others, many exemptions. They also finance faith-based organisations in all sorts of care and social services and also in education, either directly or indirectly. As already stated above, strict separation of state/politics and religion is an undesirable myth. Corporatist regimes officially recognise these relationships between governments on all levels and organised religions, but do so in an unfair, exclusivist and rigid way, privileging old majority religions, whether established or not, and disadvantaging new minority religions. Their inbuilt majority-bias and their institutional inertia prevent a smooth and adequate accommodation of the morally and legally legitimate institutional and policy-claims by new minority religions. Corporatist regimes are unfair, and not the only alternative.

Associational Governance of Religious Diversity - a moderately agonistic and libertarian, flexible version of democratic institutional pluralism - proposes a realistic third way of overcoming the inherent deficiencies of today's predominant normative institutional models. It shares with American denominationalism its preference for non-establishment and the fact that it is clearly much more friendly towards (new, small) religious minorities, as well as showing a much greater degree of religious diversity (both are considerable achievements!) than French secularist republicanism

two core characteristics as power-sharing systems: (i) the existing plurality of groups, organisations or political units are formally recognised and integrated into the political process, and (ii) a fair amount of actual decentralisation and self-determination. The most well-known variety is political/territorial pluralism: consensus-democracies and federalism in multi-level polities. The second variety is social or functional pluralism: the representation of classes, professions, elites, producers, consumers and clients in the political process in different societal fields and organisations such as firms, schools and hospitals at different levels (e.g., sectoral, regional, national and supra-national neo-corporatist councils). The third variety is ethno-religious minority pluralism. Associative democracy is a flexible, moderately libertarian variety of democratic institutional pluralism (see V. Bader, 'Problems and Prospects of Associative Democracy: Cohen and Rogers Revisited', 4 Critical Review of International Social and Political Philosophy (Special Volume) 1, at 31-70 (2001); Bader (2007), above n. 2, at 185-200 and P. Hirst, Associative Democracy (1994)), combining these three dimensions. It is meant not to replace, but to supplement, representative democracy. Compared with other types of democracy, it is driven by the conviction that all those relevantly affected by collective political decisions are stakeholders, and thus should have a say, both for reasons of meaningful democratic representation and, in particular, for reasons of governmental effectiveness and efficiency. It attempts to keep central government strong and minimal, and restrict government to its core tasks. The implied shifts from government to governance are stimulated by the institutional design of social pluralism. Social services should primarily be provided by self-governing associations, and different contents and styles of provision of social services should (be allowed to) go along with different versions of the good life. Services should be public and publicly funded, open to all, but largely non-governmental. Therefore, far from there being one welfare state (one bureaucratic formula fits all), there would be as many as citizens wanted to organise, catering to the various lifestyles of individuals and groups, but based on common entitlements. Associational service provision is a new format, for ethnic and religious groups wanting to set up their own schools, hospitals and institutions in order to care for children, elderly, handicapped and poor people. In this way, it stimulates minority pluralism, guaranteed by a strong interpretation of associational freedoms and the proposals to represent the interests of different minority groups in the political process. In the same vein, it provides meaningful exit options for minorities within minorities, thus contributing to voluntarism and plural, crosscutting membership in associations. 
and corporatist European regimes. Yet, American denominationalism has its wellknown downsides: (i) The guarantee of exit rights is not accompanied by the provision of meaningful exit options, particularly not for vulnerable minorities. The absence of a minimally decent welfare system contrasts starkly with many European regimes. (ii) American Denominationalism is known for the huge but informal impact on politics of socially and culturally established (Protestant) religions. Systems that restrict interest representation to informal ways of influencing governments through network building, lobbying etc., de facto privilege old, big, established religions because they have huge, unchecked advantages in terms of power, resources and strategies. The counterproductive consequences of a strict legal public/private split, and the relegation of religions to the private sphere of civil society, are also evident from the American treatment of political parties as purely private organisations without any public funding. (iii) This rigid public/private split is also counterproductive when it comes to a wide variety of welfare and social services ${ }^{86}$ and to new experiments in education. ${ }^{87}$

Associational governance (AG) is a realist utopia that, in principle, could build on existing regimes of governance in various countries. Institutionally pluralist regimes may, prima facie, provide better opportunities for transitions to AG because important modes of institutional learning exist in their experiences with broad and established selective cooperation, and could be combined with stronger interpretations of equal treatment, relational neutrality and fairness as even-handedness towards new minority religions. The irony of the Dutch case seems to be that these chances of moving from pillarised systems to an open, inclusive and flexible system of institutional pluralism (such as AG) paradoxically seem to have been sacrificed on the altars of an increasingly fashionable secularist-republican or nationalist-communitarian rhetoric of assimilation. ${ }^{88}$ Countries, such as the US, that lack developed systems of institutional pluralism, will have more difficulties in this regard - though quite similar experiments can be found on state and municipal levels. ${ }^{89}$

From the perspective of liberal democratic politics and normative theory (including political philosophy, constitutional law and jurisprudence), the important question clearly is not whether society and the state are fully secularised or secular and completely separated from religions. Firstly, we know that the emerging secular state has not been a liberal, let alone a democratic, state.$^{90}$ In addition, this minimalist secular state certainly did not require, or even presuppose, any social or cultural secularisation of beliefs and practices; it only required the taming of absolutist claims of religions regarding the state and the law. We all know many examples of recent secular states that have grossly violated not only minimal standards of liberal democracy but also of any minimal morality. Moreover, a highly, but certainly not completely, culturally secularised society - which can be found in some European states (e.g. the Czech

\footnotetext{
86 M. Minow, 'Partner, not Rivals?', 80 Boston University Law Review 4, at 1060-1094 (2000).

87 J. Liebman and C. Sabel, A Public Laboratory Dewey Barely Imagined: The Emerging Model of School Governance and Legal Reform (2003). <http://www2.law.columbia.edu/sabel/papers/ deweySAE3NYUEDITjslcfsedi.doc>.

${ }_{88}$ See V. Bader, 'Associational Governance of Ethno-Religious Diversity in Europe. The Dutch Case', in R.M. Smith (ed.), Citizenship, Borders, and Human Needs (2011), at 273-297. See M. Valenta, Pluralist Democracy or Scientistic Monocracy? Debating Ritual Slaughter (2012) in this ELR-volume for this double 'break with Dutch pluralist tradition' by either assimilation into 'Dutch Leitkultur' and/or by a new form of 'scientistic governance' 'in which religion is removed from the public domain, to make way for a techno-scientific framework for establishing one collective, national "truth regime" and legislating social morality' (at 4-6).

89 See my extensive treatment in Bader (2007), above n. 2, at chapters 7-10; briefly: V. Bader, 'How Should Liberal-democratic States Accommodate Religious Diversity?' IMISCOE Policy Brief no. 8 (2008) $<$ http://library.imiscoe.org/en/record/270914>, and V. Bader, 'Governance of Religious Diversity: Research Problems and Policy Problems', in M. Koenig and P. Bramadan (eds.), International Migration and the Governance of Religious Diversity (2009), at 43-72. See also the my criticism of Modood's 'moderate secularism' and Bhargava's 'principled secularism': V. Bader, 'Beyond Secularisms of All Sorts' (2011) $<$ http://blogs.ssrc.org/tif/2011/10/11/beyond-secularisms-of-all-sorts/ >.

90 See I. Hunter, 'The Shallow Legitimacy of Secular Liberal Orders', in G. Levey et al. (eds), Secularism, Religion and Multicultural Citizenship (2009), at 27-54; B. Kaplan, Divided by Faith (2009).
} 
Republic, the Netherlands and England) - certainly does not require a secularist state, but a state that is secular only in the minimalist sense of the two autonomies of state from the church(es) and the churches from the state. Rather, we should enquire which forms and degrees of differentiation are compatible with, or most conducive to, the principles and practices of liberal democracy. From this viewpoint, the meta-narrative of secularisation is deeply misleading. ${ }^{91}$ It should be de-linked from liberalism and democracy, ${ }^{92}$ and replaced by priority for liberal democracy ${ }^{93}$ or for 'liberal-democratic constitutionalism ${ }^{94}$ It is not decisive whether a state is secular; what matters is whether it is decent and/or liberal-democratic.

For more than a decade, the heated debates on secularisation and secularism in the social sciences, and also increasingly in political theory and philosophy, have infected legal theory, constitutional law and comparative constitutionalism. Generally speaking, it may indeed be too late to ban the word secular or to remove secularism from our cultural vocabulary. The argument, however, that 'too many controversies have already been stated in these terms, ${ }^{, 95}$ seems unconvincing to me. For the purposes of constitutional law and jurisprudence, this article's proposal to drop normative concepts of secularism of all forms is motivated by the conviction that, through this, we are better equipped to economise our moral disagreements, or to resolve the substantive constitutional, legal, jurisprudential and institutional issues and controversies.

With regard to the 'constitutional status of secularism' we can discern three distinct positions,${ }^{96}$ all sharing the argument that 'secularism ... in most liberal democracies ... is not explicitly recognized in the constitutional text or jurisprudence', and that it has 'no clear standing among constitutional values' either. It is 'not clear which established constitutional category secularism fits into or what is the underlying value behind it ${ }^{97}$.

The first position, defended by Sajó and others, tries to overcome the absence of secularism in most liberal-democratic constitutions and to streamline their messiness by developing a 'more robust theory of constitutional secularism' in order to remedy the fact that 'most democracies are without a strong normative theory or practice of constitutional secularism', to present a 'clear agenda' and a 'coordinated action plan' in order to 'defend' vulnerable constitutions against the threats of (strong) religions.

The second position proposes to fully contextualise secularism in normative theory and constitutional law by developing theories of alternative secularism(s): 'inclusive', 'passive', 'moderate', 'evolutionary', 'weak', 'tolerant', 'liberal', 'benevolent' or 'ameliorative' secularism, laïcité plurielle (or positive, de gestion, bien entendue) in opposition to 'exclusive', 'assertive', 'aggressive', 'strong', 'intolerant', 'statist', 'hostile' or 'malevolent' secularism (Bhargava, Modood, Jacobsohn, Shankland-Hurd, An-Na'im, Willaime, Bali amongst many others).

The third, rather radical, position is to criticise both secularism and post-secularism. Luckily, post-secularism has not yet, as far as I can establish, infiltrated legal and constitutional thinking, so we can focus on the main reasons why we believe we

\footnotetext{
91 In the context of Western state and nation building, it has been linked to the following conceptual dichotomies: religious/secular, religious/politics, private/public, traditional/modern, heteronomy/ autonomy and religion/reason (see Koenig, above n. 13, at 59-75) reproduced in liberal political philosophy (see V. Bader, 'Religious Pluralism. Secularism or Priority for Democracy?', 27 Political Theory 5, at 597-633 (1999)).

92 J. Casanova, 'Immigration and the New Religious Pluralism: An EU/US Comparison', in T. Banchoff (ed.), Democracy and the New Religious Pluralism (2007), at 59-84.

93 V. Bader, 'Religious Pluralism. Secularism or Priority for Democracy?', 27 Political Theory 5, at 597633 (1999) and Bader (2007), above n. 2.

94 V. Bader, 'Constitutionalizing Secularism, Alternative Secularisms or Liberal Democracy? A Critical Reading of Some Turkish, ECtHR and Indian Supreme Court Cases on 'Secularism", 6 Utrecht Law Review $3(2010)$.

${ }_{95}$ C. Taylor, 'Foreword. What is Secularism?', in G.B. Levey et al. (eds), Secularism, Religion and Multicultural Citizenship (2009), at xi, A. An Na'im, 'The State Cannot Be Islamic, What Does Being Secular Mean?', Conference Paper, Istanbul, (July 6-9 2008), at 6-8.

96 See more in detail Bader (2010), above n. 93, at 3.

97 A. Sajó, 'Preliminaries to a Concept of Constitutional Secularism', 6 International Journal of Constitutional Law 617 (2008).
} 
should drop secularism from our constitutional language: (i) Secularism is not only, obviously, a very complex, polysemic and - as all our basic concepts - an essentially contested concept, but also a unclear, chameleonic, highly misleading or cacophonous concept. If we are able to discuss the substantive issues of state-religion relations using clearer concepts we should do so, instead of translating everything into the language of secularism; (ii) Constitutions and constitutional jurisprudence provide for such concepts both in terms of rights or first-order principles, and in terms of underlying values or second-order principles. The absence of secularism in most liberal democratic constitutions clearly demonstrates this; ${ }^{98}$ (iii) As already stated, the really important substantive issue is not whether states and politics are modern or secular (whatever this may mean), but rather, whether they are liberal-democratic or, in other words, live up to the requirements of minimal, or more demanding but still minimal-liberal and minimaldemocratic morality, and what this means in terms of constitutional and institutional arrangements and politics/policies. To restate this in the language of systems theory: in the perspective of constitutionalism the important lead distinction (Leitdifferenz) is not secular versus religious, but liberal versus non-liberal and democratic versus non-democratic. This allows for research into, and the detection of, incompatibilities between, on the one hand, secular and religious regimes, practices and ideologies, and on the other hand, liberal and/or democratic ones; (iv) The principle of constitutional secularism does not allow for investigation, but rather, conceptually eliminates deep and serious tensions between secularism and liberal-democratic constitutionalism (e.g. in Turkey). (v) Constitutional secularism tends to hide structural tensions inherent in LDC between liberal constitutionalism (Rechtsstaat, rule of law, the older notion of Constitutionalism) and democracy (modern versus ancient democracy), and it undermines reasonable balances amongst the two in general, particularly in cases of militant democracies, such as Turkey and India.

Secularism denotes a family of concepts such as secular, secularity, secularisation, and secularism, with regard to institutions, social processes and politics, principles, and meta-narratives. In order to understand these different meanings and their relationships, we have to disaggregate or disentangle this cluster and, in doing so, we have to use ordinary constitutional or legal language instead of treating it as a poor proxy of secularism. In a detailed analysis and criticism of Indian and Turkish constitutions and jurisprudence, twelve different meanings of secularism have been established. ${ }^{99}$ This analytical taxonomy, which could also be derived from constitutions and court rulings in other countries, serves a dual aim. It helps to clarify our semantic understanding, and it allows for the discussions of our normative disagreements on LDC point by point, instead of mixing everything up. This article moves from rights and institutions, to principles and to meta-narratives or deep justifications.

\section{Secularism 1: Secularity of the state or the autonomy of the state from (organised) religions.}

Any decent and, a fortiori, any minimal liberal state, requires a certain threshold of institutional, organisational, and role autonomy, which is incompatible with theocracy and the replacement of state-law by encompassing religious law. This may be the least contested meaning of secularism. Yet it is also obvious that Western states were not secular in early modernity, that even nowadays none of the existing states is strictly secular, and that so-called secular states, such as Nazi Germany, the Soviet Union, Cambodia under Pol Pot, Iraq under Saddam or Libya under Khaddaffi, have violated minimal morality as often as, or even more so than, so-called religious states. Thus, the

\footnotetext{
98 Only a tiny minority of constitutions declare states to be secular: France, Poland, Portugal, Russia, Serbia and the Slovak Republic in Europe; Mexico and India and some African and most post-Soviet states (see J. Temperman, State-Religion Relations and Human Rights Law (2009), at 125f). In these cases, Constitutional Courts would clearly have difficulty in totally disregarding the term secularism, but they should not be allowed to block constitutional amendments (as in Turkey). As I wish to show, it would be better if they tried to explain what they mean without using the term.

99 See extensively Bader, (2010), above n. 93, at 3.
} 
secularity of the state is certainly not the same as normatively praiseworthy secularism, and the tricky issue involves spelling out the minimal threshold of differentiation of state, or even politics, from religion, since strict separation is, as we have seen, a nonstarter.

\section{Secularism 2: Equal associational freedoms and collective toleration.}

LDC requires not only this first autonomy, but also a second autonomy of religions from the state, which is extensively violated by self-declared secular states (such as France and Turkey) through massive state-supervision and -control of religion. This version of secularism 1 is inimical to external and associational religious freedoms, and clearly incompatible with liberal constitutionalism 1. Collective toleration and associational freedoms are clearly not modern, liberal inventions, but liberal constitutionalism additionally requires equal legal associational freedoms and non-discrimination, not fully guaranteed in pre-liberal arrangements (e.g. in the Ottoman Empire).

\section{Secularism 3: Freedom of conscience and individual religious freedoms.}

The protection of freedom of conscience and of individual religious freedoms against the state, against all majorities - secular as well as religious majorities - and against all minorities (and their organisations) is a specific modern requirement of liberal constitutionalism 2. Yet, individual and associational religious freedoms are often in tension with each other, and this inherent tension between liberal constitutionalism 1 and 2, or in more common language, this conflict between individual and collective religious rights, is often neglected or downplayed in three ways. Firstly, by declaring religious freedoms as primarily a matter of individual conscience in the private sphere, and neglecting or severely curtailing external and associational freedoms. Secondly, by massive and illegitimate state intervention in the internal affairs of religious associations even in core issues of belief and practice. And thirdly, by doctrines and practices of unconditional or absolute deference that do not protect even the most basic rights of minors, women and dissenters within majority or minority religious groups and organisations. ${ }^{100}$

\section{Secularism 4: Protection of religious minorities against unbound democratic majoritarianism.}

Liberal Constitutionalism, in addition, requires the protection of individual and associational civil rights and of minority rights. As such, it is generally incompatible with unbound democratic majoritarianism: liberal-democratic constitutionalism is constitutional democracy, not only majority rule. This liberal constitutionalism 3 is particularly important in two situations: Firstly, in cases of aggressive secular majorities - and even more so in cases of aggressive secular ruling elites not forming majorities, as in Turkey - threatening to seriously restrict equal religious freedoms of religious majorities and minorities. Secondly, in countries with potentially or actually totalistic, illiberal religious majorities which threaten - by majority-decision - to restrict equal freedoms from religion (of secular or non-religious people) not to believe and practice any religion, as well as the freedoms of religious minorities. Liberal Democracy is, as we should know, a fairly late historical and theoretical compromise of freedom and democratic equality, full of internal tensions.

Before turning to democratic constitutionalism, let me point out that these four pillars of liberal constitutionalism are phrased here in traditional constitutional terms; calling them secularism $1-4$ clarifies nothing, and brushes over the tensions and incompatibilities between liberal constitutionalism and secularism.

\footnotetext{
100 See for the importance of exit rights and exit options: V. Bader, 'Individual and/or Associational Autonomy? Associative Democracy and the Freedoms of Entry and Exit', in D. Borchers (ed.), Theoretical and Practical Implications of the Exit Option in Liberal Societies (forthcoming).
} 
Secularism 5: Popular sovereigntyand protection againstpoliticaldiscrimination: political secularism or secular democracy.

Modern democracy, again different from ancient, but also from classical, liberal democracy, stands for vox populi vox dei, for equal political status of all citizens and for equal political rights in opposition to all ascriptive discriminations, particularly on religious grounds. This is often called political secularism or democratic secularism. As in the case of the secularity of the state, one can call any democracy that does not discriminate on religious grounds a secular democracy. Thus, modern democracy is secular by definition, indicating popular sovereignty, or the condition that all defenders of absolute truth-claims, religious as well as secular ones, have to solve their respective fundamentalist dilemma that their absolute truths are treated as opinions when it comes to democratic decision-making. Yet, identifying secularism and democracy, or declaring their deep harmony, makes it impossible to see and investigate serious tensions. In my view, secularism can be, and actually is, inimical to modern, democratic constitutionalism, at least in four regards, and ironically, all these serious restrictions of democracy are legitimised as being necessary in order to defend democracy. Firstly, modern democracy requires a free and equal political process and multiparty competition, and these minimal institutional requirements of democratic constitutionalism 1 have often been violated by secularism as an aggressive, elitist strategy of modernisation (e.g. by Kemalist secularism). Secondly, massive restrictions on the freedoms of political association, prohibition of political parties and dismissal of elected MPs, assemblies and even elected (state-)governments by militant democracies, such as Turkey or India, are inimical to this second core element of democratic constitutionalism. Thirdly, free speech, its third core element, is often violated or seriously restricted by secularismrestraints (see secularism 6). Fourthly, many varieties of foundationalist secularism (10 -12) are inimical to its fourth core element, the pluralist, non-foundational character of modern democracy.

\section{Secularism 6: Freedoms of political speech or exclusivist secularism?}

Freedoms of political communication, particularly of political speech, are the core of a liberal understanding of modern democracy, as opposed to elitist, majoritarian or statist restrictions. Restrictions on public reason or political speech by excluding religious reasons (as still defended by Habermas, see above) extend beyond legitimate restrictions on grounds of incitement to violence and serious discriminatory speech. Exclusivist secularism (in politics, law, constitutional jurisprudence or philosophy), incompatible with liberal democracy and inclusive secularism, does not clarify the issue: at stake is not the secular or the religious character of speech, but whether or not it presents a clear and present danger or seriously discriminates.

\section{Secularism 7: A social or a socialist state?}

Many constitutions require the state to be a social or even a socialist state (e.g. India), but what has this to do with secularism? On the one hand, one might say that the guarantee of basic subsistence rights (not just charity) to all citizens/residents should not allow for religious or all other ascriptive discriminations or exclusions. Yet, on the other hand, LDC seems compatible with a wide institutional variety of welfare regimes (faith-based providers amongst them) whereas secularism would require state-provision only, excluding faith-based welfare provisions.

\section{Secularism 8: Strict separation? Strong or moderate, benevolent, ameliorative secularism?}

In terms of institutional arrangements, the principle of secularism seems void and indecisive, allowing for both strict separation as a non-existent utopia (strong secularism), as well as various existing or alternative forms of selective cooperation between states, politics and (organised) religions. Does LDC require one state-law only for all citizens/residents, as strong secularism holds (as the Turkish Constitutional 
Court, endorsed by the Grand Chamber of the ECtHR in the Refah case 2003 declared), or is it compatible with limited opportunities for religious legal pluralism in marriage and divorce law under conditions of freedom of entry and exit and voluntary choice of law (of limited scope), and of state guarantee of basic interests and rights (as a whole variety of weaker versions of secularism suggest)? ${ }^{101}$

Secularism 9: Strict neutrality or relational, inclusive neutrality, principled distance? Strict equality or fairness as even-handedness?

Second order principles are unavoidable; yet, highly abstract and indeterminate meta-rules (expressing something like the constitutional creed or faith), which may help interpret and balance conflicting legal principles and rights. The issue is whether secularism in general (or secularism-as-strict-neutrality and strict equality) contains the right principles in this regard, or wether these principles should rather be reconceptualised as relational or inclusive neutrality, or as fairness as even-handedness in cultural and religious matters (as I have argued with Carens, Bhargava, Ferrari and others). ${ }^{102}$

\section{Secularism 10: Ethical secularism?}

Though modern, pluralist democracy cannot be strictly anti-perfectionist, it should be as anti-perfectionist as possible; ${ }^{103}$ it should not explicitly privilege a specific way of leading a good life (e.g. a comprehensive liberal ethics or a secular, humanist ethics as a supreme way of life). Ethical secularism (as declared by the Turkish Constitutional Court) - distinct from political secularism - is surely incompatible with LDC.

\section{Secularism 11: Foundational or justificatory secularism?}

Liberal-democratic constitutionalism does not require any deeper, metaphysical, philosophical or theological, normative foundation. Modern, pluralist liberal democracy is an open project helping to prevent the political form of a society from being seen as the realisation of a transcendent vision or an ultimate philosophical foundation. Secularism, also in this regard - e.g. the exclusivist claim of an independent political ethics mode (from Bayle and Spinoza to Habermas - see above) - is rather parochial (secularist or humanist enlightenment exclusivism), and potentially or actually inimical to liberal-democratic constitutionalism.

\section{Secularism 12: A generalised meta-narrative or symbolic universe?}

LDC thrives through competing symbolic universes (i.e. overarching cognitive and normative views of the cosmos, nature and society), and constitutionalising secularism as a meta-narrative of rationalism, science, modernisation or civilization (as in Turkey or India) is incompatible with the open character of pluralist democracies. It induces Contitutional Courts to declare rationalism or scientism as a general foundation and/or universally accepted ideal, to construct all religion as dogmatic and inimical to humanity, civility, freedom, democracy, and to speculate on the true, essential meaning of religions by declaring all contrary official statements of religious parties and representatives as a pretext.

By way of conclusion, I hope to have made plausible that appealing to the principle of secularism does not help to clarify, but rather, mystifies our normative disagreements

\footnotetext{
101 See RELIGARE Work Package 3 (RELIGARE website - database on intranet, not yet publicly accessible) for an overview of the case-law in family- and divorce law in many EU Member States and Turkey.

102 See also K. Henrard, Duties of Reasonable Accommodation in Relation to Religion and the European Court of Human Rights: A Closer Look at the Prohibition of Discrimination, the Freedom of Religion and Related Duties of State Neutrality (2012), in this volume of ELR.

103 Bader (2007), above n. 2, at 74-79.
} 
regarding the difficult contextual task of weighing or balancing tensions of constitutional principles and conflicting rights. All attempts to do so end in boundless ambiguities and an inflation of competing varieties of secularism that are incompatible with each other.

Replacing secularism with LDC should not be misunderstood as a replacement of one ideology (secularism) with another equally cacophonous or ambiguous one (liberalism). LDC is not a foundational ideology or philosophy, but a meta-constitutional and meta-legal ideal ${ }^{104}$ containing the constitutional essentials, or the core, of various and differing articulations of rights and principles in liberal-democratic international or regional conventions and state constitutions. It is compatible with many competing theories of the rule of law and of democracy, but does not depend on any of them, including political liberalism. ${ }^{105}$

\footnotetext{
104 The logical status of Liberal Constitutionalism over legal positivism and natural law is nicely explained by Friedrich Hayek ('The rule of law is therefore not a rule of law, but a rule concerning what the law ought to be, a meta-legal doctrine or a political ideal' (F. Hayek, The Constitution of Liberty (1960), at 206); Franz Neumann and others.

105 See V. Bader. 'Reply, 'Review Symposium: Historic settlements and new challenges: V. Bader, 'Secularism or Democracy? Associational Governance of Religious Diversity', 9 Ethnicities 4, at 559, $567 \mathrm{f}$ (2009).
} 